\title{
Policing Migration and Racial Technologies
}

\begin{abstract}
Alpa Parmar*
Abstract

The merger between familiar modes of policing with the impetus for migration control is reorganising the racial politics of policing in unexpected ways. In the aim to decipher who is a citizen, who is a foreign national offender and who is eligible for deportation on the grounds of criminality, the role of criminal records agencies has expanded further into the work of policing, as have the collaborative working partnerships between immigration and the police. In this paper I discuss the findings from research which examines the policing of migration in the UK and specifically Operation Nexus which brings together ordinary police work and migration control. I focus on how technologies of border control are imbricated with everyday police practices that are often influenced by race, thereby deepening the reach of racial technologies and their capacity to monitor and exclude racial others.
\end{abstract}

Keywords: race, technology, policing migration, surveillance, police custody, foreign national offenders

\section{Introduction}

This article examines the relationship between technology, police culture and migration control. I discuss how technology enables and extends the hyper surveillance of racialized migrants and show how the imperative to deal with foreign national offenders facilitates and rationalizes this process. Drawing on observations of police custody suites and interviews with police custody personnel and criminal records analysts, I analyse the implications of technology in policing through the lens of race. First, I discuss scholarship on technology, race and the criminal justice system and advance the conceptual framework adopted in this paper which brings together these disparate disciplinary perspectives, whilst keeping central the focus on how race operates in and mediates these spaces. Second, I discuss the policing of immigration in the UK, 'Operation Nexus' and the methodology I adopted for the research. Thirdly I discuss the thematic findings and show how technology was able to animate race in police custody spaces. The conclusion proposes the need for better monitoring, more critical examination and improved control over how policing adapts to and implements digital technologies. I argue that the analysis of surveillance and technologies should be explored in the context of the criminal justice system, not only as a site of racism, but also where race is made, reproduced and embedded through mundane repetition and quotidian activities in which technologies increasingly shape police work.

\section{Policing Borders, Race and Technologies}

The targeted policing of migrant groups has long involved demarcating those who belong and do not belong in order to 'sort' non-citizens from citizens (Weber and Bowling, 2004; Waddington, 1999). This paper examines how race continues to operate according to these organizing principles. It shows how border control when practiced in the realm of policing draws on established racial tropes while also accommodating new modes of racialization. This is accomplished partly through police culture, the employment of technological tools and through the joint working practices, data sharing and alluring expectation of progress and neutrality that technology promotes. Technologies are only as good as their makers and they bear the imprint of their designers and culture. Thus histories of discrimination live on in digital platforms and become part of the logic of everyday algorithmic systems and risk assessed prediction (Wajcman, 2017; Hannah-Moffat and Maurutto, 2010), and are increasingly used in policing (Ferguson, 2017). Although Social Studies of Technology (SST) is a long-standing and burgeoning field, assembling scholarship on science, technology and race is not an easy task as it involves bringing

*Centre for Criminology, University of Oxford, St Cross Building. Oxford, United Kingdom.

OX1 3UL.alpa.parmar@crim.ox.ac.uk 
together different disciplines and a significant amount of detective work, particularly because race has dropped down the academic agenda of SST (Skinner and Rosen, 2001). The relative silence of race in criminal justice debates (Parmar, 2016) makes the task of bringing together SST, race and criminal justice questions more complex. Recognition that science and technology are developed and used in racialized social settings and that the criminal justice system is one of key institutions that racializes populations today, is a point of crossover that beckons criminologists' and migration scholars' attention. Understanding how technological devices (e.g. databases that link immigration status and crime information) are implicated in processes of race-making and unravelling the articulations of race in the traffic between databases and societies is necessary as modes of governance are increasingly digitised (M'charek et al., 2014; Benjamin, 2016).

The policing of migration typifies how somatic and visual difference (particularly darker skin tone) continues to matter regarding who is targeted for further scrutiny and suspected to be a foreign national, an offender or an illegal immigrant. Race, at both the visible and invisible levels, continues to be a productive relationship where crude and the subtle forms of racism reinforce each other (BonillaSilva, 2018). Read this way, the police response to migration control through an increasing reliance on technologies offering instant access to databases and other personal information, enables race to mediate and influence the identification and expulsion of undesirable, criminalized, racialized people from the national body, without explicitly appearing to be about race. In this paper, the findings focus on police custody spaces which are complex arenas where people are transient, and which evoke emotional reflection and 'aftershocks' (Woof and Skinns, 2017). I found that the experience of foreign nationals suspected of offending and unfamiliar with the procedures in custody confirmed the lasting impacts of these emotive spaces, thus underlining the importance of empirically excavating how race is animated in police custody. Ethnographic policing as a mode of data capture was vital for revealing the way that national level border and security policies were enacted and experienced at the local level (Loftus, 2013).

\section{Police Technologies}

Technology has been widely heralded as the source of efficiency in modern policing and previously its utility was virtually unquestioned publicly (Manning, 2008). Concerns are beginning to be raised about the limits of technology when applied in police decision making processes and the unintended consequences of using data and algorithmic analysis to predict the risks posed by people in police custody in the UK (Oswald et al., 2018). Criminal justice technologies have been scrutinised mostly in US scholarship for their racial logics and capacity to reproduce and mimic human racial bias (Noble, 2018; Ferguson, 2017). Nevertheless, despite the increasing ubiquity of new technological tools in policing, less is known about their effectiveness, the nature of their implementation, and whether expectations of increased efficiency are indeed met. Predictive policing technologies can give rise to an 'accountability gap' as individual officer accounts of decision-making processes are undermined and potentially deflected or outsourced to the software rather than the human (Bennett Moses and Chan, 2018). The adoption of new technologies is connected to many aspects of policing including daily routines, community interaction and internal relationships (Lum et al., 2016) and intersects with preexisting police cultures as opposed to straightforwardly transforming them; 'technology is a chameleon: it simulates its environment' (Manning, 2008). Furthermore, decisions about when to apply technology and where, are uneven and discretionary. The consequences of the application of technology are thus frequently disproportionate in terms of race, gender and class, yet the accountability for such outcomes are diffuse and paradoxically harder to trace and attribute.

\section{Technologies, Surveillance and Race}

The use of some technologies by the police is often rationalized for their potential to democratize policepublic encounters, reduce individual officer discretion in police practice, and promote objectivity (Joh, 2007). However, the actual benefits against these aims have been less convincing and research on the growth of police technologies remains largely silent on matters of race (Amar, 2010). The integration of body worn cameras in policing in London in 2016 for example was ushered in amidst suggestion that they might mitigate against the disproportionate numbers of black men stopped and searched by the police, and because the cameras are presumed to introduce accountability and transparency mechanisms that mediate police-public encounters in real time (Coudert et al., 2015). However, such assumptions 
are based on findings showing that police body worn cameras reduce complaints about the police and not on what the public and in particular racialized groups actually think about them (Ray et al., 2017), making their effects complex to disentangle. In the UK, body worn camera footage has not shown a reduction in stop and searches of black and Asian people (Grossmith et al., 2015) and rather has provided evidence of excessive restraint when officers interact with racialized groups (Weaver, 2017). Cameras have inadvertently served as a form of data capture, showing that the language used by the police in encounters with citizens varied by race in that officers consistently spoke with less respect towards black people compared to white people (Voigt et al., 2017). Furthermore, artificial intelligence learns from examples it was trained on, so implicit or explicit human racial biases are reproduced through the application of the criminal justice technologies (e.g. facial recognition) and expand the over-surveillance and inaccurate identification of black bodies resulting in 'algorithmic discrimination' (Noble, 2018; Skinner, 2018; Garvie et al., 2016; Buolamwini, 2018; Bowles, 2016).

In examining the links between biometric information technology and transatlantic slavery, Browne (2015) argues that branding was an early form of racialized surveillance because of its dual purpose of meting out corporeal punishment as well as serving as a means of identification of who was the owner of a slave. Other scholars too have argued that surveillance is inherently racialized (Fiske, 1998). Correspondingly, the collection of biometrics in the present day, according to Browne's thesis, is the commodification of information, of and about the body. Measuring the living body allows the body itself to function as evidence (Cole, 2002) or as a form of identity management, where the body acts as a password (Aas, 2006; Muller, 2004). In my research I saw that biometric data capture was embedded within the institutional logic of police custody and the quotidian management of bodies that passed through the space. All suspects were processed in this way, however suspected illegal migrants were checked against police and immigration databases; the six occasions where I saw DNA samples forcibly taken were all from visible racial minorities who were foreign nationals. Migrants and their bodies were used to access and unlock 'data', to prove or allocate an identity alongside an assemblage of criteria that rendered some particularly suspect, and it is to this discussion that I now turn.

\section{Policing (Im)migration}

The collaboration between policing and immigration is not new, Paul Gordon, writing over thirty years ago (1985), highlighted the increasing use of technology and the role of the police in enforcing immigration laws. The entwinement of immigration and criminal law and expansion of 'crimmigration' now works to exclude those deemed undesirable or unworthy from society (Stumpf, 2006), and correspondingly the enforcement of immigration and criminal law have also become less distinct. The convergence between everyday policing, border control and citizenship has been shown in jurisdictions across the world, demonstrating that there are now multiple 'sites of enforcement' for border control (Weber and Bowling, 2004). Many different bodies are on the move and it is through their movements that bodies are marked as 'different' in the first place (Ahmed, 2000). Policing is increasingly preemptive; risk profiling and surveillance are directed toward more groups whose citizenship is in dispute (Weber, 2013). Formalisation of police powers across the world to carry out immigration duties has meant that the border has multiplied, checkpoints are everywhere (Mezzadra and Neilson, 2013), and the public are enlisted into suspecting whether people are illegal migrants to the extent that we have 'everyday bordering' (Yuval-Davis et al., 2018; Aliverti, 2015). In the sections that follow I show how the ubiquity of the border dovetails with an increasingly technological police force.

\section{Operation Nexus}

In the UK, the need to 'manage migration' has prompted various adaptations to local police work and collaboration with immigration and identity/criminal history verification agencies. Operation Nexus launched in London in 2012 and has been rolled out across the UK since 2014 to make the identification, removal and deportation of serious and prolific foreign national offenders more efficient (Vine, 2014; Bolt, 2016). Nexus has two strands - the first deploys immigration officers to designated police custody suites to examine all foreign nationals who are arrested and held in custody. Those people who are identified as illegal entrants are then referred to Immigration Enforcement's National Removal Command for case progression. The second strand involves the police referring people classed as foreign national offenders and 'high harm' to a specialist team because the individual is deemed to be a threat to the public. The High Harm team then provides specialist casework resources to the police 
and assists with pursuing both deportation and administrative removal against people defined as foreign nationals (Home Office, 2017a). Such advanced level approaches to identify foreign national offenders as efficiently as possible has demanded information sharing and database access that extends beyond agency boundaries. In practice, in all police stations, whether Operation Nexus is implemented or not, people suspected of being illegal migrants are checked for previous offending. Foreign nationals brought into police custody suspected of non-immigration and immigration related crimes are also asked about previous offending in other or 'home' (country of origin) countries. If crimes are identified and are serious enough, they may be removed on grounds that they constitute a harm to public safety. These more serious offenders are supposed to be the real focus of schemes such as Operation Nexus; however, in practice, Nexus has been criticised for being used against low level criminals deemed as easier targets (Griffiths, 2017; Yeo, 2017).

The questions that suspects are asked about their previous offending are verified against crossnational systems through information sharing agreements with other countries and with the assistance of the Association of Criminal Records Office (ACRO) and the Home Office. ACRO is a police-funded identification verification body that holds criminal records and makes requests to EU and non-EU countries about individuals and their criminal conviction history in different jurisdictions. ACRO aims to provide the police with information about previous convictions as quickly as possible so that if the suspect is wanted in another country or has committed crimes serious enough to make them eligible for deportation, the police can refer the suspect to the Criminal Cases Directorate or the High Harm Team for removal proceedings to be put in place. The Home Office is often able to verify immigration status and ACRO can make requests to the 'home' country to see if the person is wanted or has a history of crimes there or in other countries. The ACRO database may hold fingerprints of those previously convicted, or ACRO can request fingerprint files from the relevant country's police and intelligence agencies. Fingerprints taken by the police are also checked against the Home Office biometric database which holds finger print scans of all visa applicants and those naturalized in the UK since 2008 (Bolt, 2016).

\section{Methodology}

From late 2014 to 2017, as part of a larger study to explore the changing nature of policing in relation to migration, I observed shifts in police custody suites and interviewed police officers, police staff, immigration enforcement officers and ACRO analysts to understand how foreign national offenders are dealt with in places that adopted Operation Nexus as well as those that have not. I carried out two hundred hours of observation and forty-eight interviews with police custody sergeants and police custody staff at various locations in England. Sworn police officers of various ranks were observed and interviewed, as well civilian police staff (custody detention officers/dedicated detention officers). Typically, a police custody sergeant would always be present in the custody suite, alongside a team of between three and eight custody detention officers depending on the size and location of the suite. Police staff were often employed by private firms (e.g. G4S, Tascor) but some suites were served by detention officers that were employed directly by the police force. I also observed street level police officers who would bring suspects in to detain and criminal intelligence desk officers tasked with investigating cases within the twenty-four-hour period that people could be held for in police custody. The sample of police officers and custody sergeants observed and interviewed predominantly from white British backgrounds (22 out of 28), the remaining six were white British Eastern European British (4), British Chinese (1) and British South Asian (1). The custody detention officers included more British South Asian Indians (7 out of 20) and the remaining 13 were made up of ten white British and three white Eastern Europeans. The majority of the police officers and sergeants were male (21 male and 7 female) and similarly, most of the detention officers were male (18) and two were female.

The police participants I observed will have approached their role and implemented their work ethos in divergent ways, and in this article I focus on the broad observations and interview themes that were revealed without separating out the different approaches adopted by participants. My aim was to capture the practices that contributed to the overall culture of the custody suites and how foreign national suspects were treated under Operation Nexus. The definition of 'police culture' that I adopted throughout the research focussed on the 'values, norms, perspectives and craft rules of the police' whilst also recognising that police culture is mutable and varies between police force areas and individual custody suites (Reiner, 2010: 117-118; Foster, 2003). Following the recommendations made by the 
Macpherson Report ${ }^{1}$ in 1999 , research indicated that diversity initiatives in policing had resulted in cosmetic adjustments rather than deeper level attitude change (Foster et al., 2005). Hence I was interested in whether diversity and anti-racism in the police work that I saw was embraced, resented or resisted and seeing if/how race and migration control duties of the police intersected in modern policing contexts (Loftus, 2008; Loftus, 2009). In my attempt to understand internal borders I was able to witness the embodied experience of migrants when they come in direct contact with local police (Mutsaers, 2014).

British Society of Criminology ethical procedures ${ }^{2}$ were followed and participants were given informed consent and the choice to withdraw from the research at any point. In negotiating access, I agreed to anonymise the names and details of participants as well as the location of the research. All identifying features are thus removed from this paper and pseudonyms used throughout. Suspects brought to custody were told about my presence as a researcher and asked permission for me to observe their interactions at the charge desk and around the custody suite. The complexity of police collaboration with other agencies such as the Home Office Immigration Enforcement Service and variation in practices across police forces, mean that seeing and experiencing how processes occur is vital for gaining a nuanced understanding of police work and for understanding the perspectives of those people subjected to border policing powers (Brouwer et al., 2017). The research discussed in the next section shows how race, technology and the management of citizenship and offending came together. These vivid examples are necessarily my own perception of situations, interactions and spaces whilst I was present. I recognise that some of the officers and staff will have perceived themselves as performing their roles fairly, transparently and consistently without intending to be racially discriminatory and perhaps even trying to delimit uneven practices towards black and minority ethnic groups. My approach however was not to measure the extent of racism or to explain if it was intentional. Rather I was interested in whether/how race operated in a context where crime control and the management of migration entwined through daily police work.

\section{Being Processed}

When suspects are brought into police custody, there is a clear procedure to 'process' people and for them to be 'booked in'. This step by step procedure is governed by the requirement to enter information onto custody suite computer programmes including 'LiveScan' and the computer database called 'Niche'. Many non-white suspects were asked to confirm their nationality, whilst British citizenship was often automatically assumed to be held when white suspects were booked in to the custody suite (Parmar, 2018a). The focus on the police establishing whether a person has leave to remain in the UK is consistent with growing research signalling the expanding governance of non-citizens through migration control (Bosworth and Guild, 2008). Ascertaining accurate citizenship information was often difficult when there were language barriers and so telephone interpreting services were used. At other times, iPads were used with suspects which had a pre-loaded 'app' called 'Ask ERIC's launched on the screen which displayed flags of the countries of the world. Suspects were then asked their 'home' country or nationality using the screen. Once identified, this would allow officers to ask suspects for the relevant information in a language familiar to the suspect and to request documentation and offending history checks to be made by ACRO.

Although in principle, this may appear a benign practice to establish which information needed to be requested from the 'home' country, its application was unevenly directed towards visible ethnic minorities because they were most often suspected of not holding British citizenship. The process ostensibly circumvented legal rights procedures, as suspects would unknowingly potentially provide information to officers (or information that could incriminate them) without the benefit of due process protections that might accompany communicating verbally. From what I saw, this put vulnerable migrants not familiar with the custody process at a distinct disadvantage. They were often frightened of

\footnotetext{
${ }^{1}$ Following the racist murder of Stephen Lawrence in 1993, the Macpherson inquiry into the murder and the police investigation made 70 proposals to reform the British police who were classed as 'institutionally racist'. ${ }^{2}$ See http://www.britsoccrim.org/documents/BSCEthics2015.pdf

${ }^{3}$ ERIC is short for European Request Information Capture and is an application developed by ACRO to assist the police in requesting the correct documentation and information to be requested by ACRO and potentially the suspect. Further information is available here https://www.acro.police.uk/eric.aspx
} 
unknown aspects of the custody procedure and were anxious about what might happen to them. In these circumstances the relative familiarity of the iPad was positively received and at times seen as a neutral, unobtrusive way of co-operating. The integration of technology into their communicative practice from the outset could be both discomfiting and reassuringly familiar for those who were not acquainted with the custody process. In practice, the presence of an iPad, the iconic technological object of the early $21^{\text {st }}$ century, in the stark, austere space of police custody was jarring. The antiquated clang of keys jangling and turning in locks was juxtaposed with the benign touch screen application behind which flowed the less than obvious shared databases and software that propelled a chain of criminal history and identity checks from different countries across myriad legal jurisdictions.

These findings may appear incongruous against the context of legislative procedures and safeguards with regard to the custody process introduced under the Police and Criminal Evidence Act 1984 (PACE). PACE has been valuable for providing comprehensive rules and outlining suspects' rights and entitlements and whilst their case is investigated and ensuring protection to police officers with regard to allegations made by suspects of mistreatment whilst in custody (Maguire, 1988). More recently, protecting the needs of those who are vulnerable in custody has been recognised, including children, those with mental health problems and people from black and minority ethnic backgrounds (HMIC, 2015). Police custody is a multi-professional context nowadays; a range of actors are admitted including independent custody visitors and appropriate adults. However, despite the increased accountability these developments suggest, my research found that informal practices and cultural norms resulted in the uneven application of procedures alongside and underneath formal policies and legal procedures. Whilst PACE may provide a framework for how police custody ought to function, the reality can be quite different (Skinns, 2011). Technologically prompted procedures such as completing custody records, performing risk assessments and background checks were compelling in their capacity to give the illusion of sameness and colour-blindness. However sustained examination revealed how technology provided scope for individual officer agency and police culture to nevertheless apply, as discussed in the next section.

\section{Retrieving is Believing}

When a suspect is brought in to custody and booked in, they are asked about their previous offending history. The information provided by the suspect is then checked against the Police National Computer database (PNC) or Crime Reporting Information System (CRIS) to see if the suspect's declaration matches the police record. In my observations of this process, I saw that information held on the PNC (or presented as being held on the database) was at times used a means to unsettle suspects in order to establish a claim of access to the 'truth' or to inveigle them into thinking it was better to 'come clean':

Officer: Can you tell me your address again please?

Jake: Yeah, it's 68 Scatham Close. Like I just said.

Officer: Any prior offences, have you been in prison, arrested?

Jake: Nah.

Officer: Well, the computer tells me something different. Are you sure you don't want to tell me the truth?

Jake: I am telling you the truth, man. No priors. Just let me go man... I ain't done nothing wrong.

Officer: Look... I've not got time to mess about. I'm asking you again. [pauses] I have the information in front of me, so you better to be upfront and come clean. It's less of a waste of your time and mine. I'm giving you the chance to tell me what I am seeing on the screen. The computer record says that you are known to the police and were in prison until recently.

Jake, a Black male in his 20s, was from South London and arrested after leaving a property that the police were watching and therefore became 'a person of interest'. The immigration officer that was present was tasked with checking the Home Office database to ensure Jake had British citizenship as well, and this was instantly possible because Operation Nexus was in place. He was confirmed as being a dual Nigerian-UK citizen and the outcome of the interaction above was that there was a mistake made by the custody sergeant in entering the information onto the PNC and another record pertaining to a 
person with a similar name was brought up. The officer mumbled an apology and Jake was held for another few hours whilst his mobile phone and car were searched by the Criminal Investigation Department. Nothing was found and so he was released with no further action. Although the racialized aspects of this interaction might seem imperceptible, its implications could be substantial. I observed this double bluff approach on a number of occasions, where prior offending was assumed and expected often in relation to black, Asian and Eastern European men. This may have possibly been because the police were seeing, on a daily basis a disproportionate number of minority ethnic group men who would deny previous convictions or being known to the police. And so, the institutional-cultural logics of the police sergeant's approach may have adapted in response to this expectation resulting in more scepticism towards black and minority ethnic men when they were being questioned. The extent of these interactions is less the focus of this paper as the argument is not that explicit racism was rampant in the police custody suites but rather that stereotypes and racialized expectations were able to mediate and inflect officer-arrestee interactions and reflect in custody spaces at times via technology and because of the assumption that data was inherently objective.

Another time, a South Asian Indian foreign national man who was being held upon suspicion of grievous bodily harm was asked his details, which were then entered onto the PNC. After staring at the computer screen, pausing and after a discussion with the immigration officer the sergeant commented, 'Mr Vasant. It seems you are well known to the police. And you do not have leave to remain because your visa expired a long time ago. Will you be needing a solicitor?' Mr Vasant replied incredulously that he had never been involved with the police, never been arrested in his life and that the computer record was wrong. 'That can't be', the sergeant replied. After a few minutes of further discussion with the immigration agent, the sergeant conceded that a misspelling of Mr Vasant's name was entered into the system and therefore the record pulled up referred to someone else and it was a mistake. Mr Vasant looked temporarily relieved but muttered 'just can't trust these people' under his breath as he was taken to a cell.

Computers and digital technologies were frequently used in this way to make suspects feel less confident about what they had declared, as the incidents above with Jake and Mr Vasant demonstrate. Although data systems are often inaccurate because of names being entered wrongly and spelling mistakes causing inaccurate retrieval, the point is that computerised data was presented as irreproachable and often emboldened officers in the challenges they directed at suspects with regard to offending histories and a person's immigration status despite the consternation it would cause. For example, Solomon, a black foreign national man brought in for suspected burglary was told the following:

Custody sergeant: Your prints match those found at the property and we have other reasons to believe this was you. You have previous gang involvement and you are not British. If we present this to the CPS [Crown Prosecution Service] and then you are up in court, it's gonna be difficult to defend. Chances are you'll have removal procedures initiated against you. Do you have anything you'd like to say to me?

Solomon: Look, man, I'm telling you, I wasn't even in the country two days ago.

Instances such as these where suspects were invited to informally offer their version of what had happened or to plead guilty at an early stage, were common, regardless of the race of suspects. However, the over-representation of black and Asian men that were brought into custody meant that a significant number of those who were visible ethnic minorities, socially disadvantaged and with vulnerable citizenship statuses were being subjected to this threat of retrieval from both police and immigration databases. Added to this was the possibility that further checks could be made by contacting ACRO if necessary. Combined with the mistrust and lack of confidence in the police amongst younger black men (Home Office, 2017b) it was apparent that electronic data were also seen by suspects as an extension of police attitudes rather than a source of neutral information. The over-policing of black and minority ethnic communities means that processes such as predictive policing patterns and the retrieval and management of digital information are likely to in fact reveal patterns about racialized surveillance (Byfield, 2018). 
Indeed, the veracity of the digital information held on police databases was less convincing from the suspect's point of view, as the following comment from Gerard, a black Moroccan foreign national suspected of robbery, highlights:

Gerard: Yeah, even if there ain't nothing on the system... you can put it on there. I know... I'm black. Like you can't add anything you want on it? [sarcastically] I know.

An understanding that police had the power to change or create information was expressed a number of times. Ali, a Pakistani foreign national suspected of arson protested, 'I don't believe your systems. How do I know what information you really have and what you don't?' In contrast, the reliability of data and the power of retrieval and access to records was something that officers talked about as promoting objectivity and the process was regarded as unbiased and mundane. According to one officer: ' $I t$ 's $a$ life-saver usually because we can verify things in an instant, ask further questions, I can try and establish address and obviously, if someone's not complying and giving you mickey mouse as their name, then you've got other ways to trace them. Now we have instant access to immigration enforcement databases too it's much better-there's just a procedure you are forced to follow.'

Another officer demonstrated how being able to rely on the system meant that he felt relieved because he wasn't making the decisions. When referring the details of a foreign national offender to the immigration officer who was embedded in the same police station, he described how it was the system telling him what to do and that following procedure encouraged transparency and fairness. He explained: 'I just have to go with what's in front of me, on the screen. So, there's very little discretion on my part. And it's a relief. I have to follow the protocol... that way I've done all I can to prevent against any unfairness.' As shown in this quote, officers often saw themselves to be working in good faith and at times explicitly to limit discriminatory practices. However, what these examples signal are the unintended consequences of information systems and how the distancing of overt decision-making practices can nevertheless lead to increased levels of scrutiny for target groups such as foreign nationals or black and minority ethnic suspects. What I found was that such uneven processes and outcomes can coexist alongside the blanket of neutrality and the attenuation of moral agency on the officers' part. Further exemplifying the contours in actual practice, there were clear differences in the procedures that were adopted for dealing with foreign national offenders which were regarded as 'coming from above' (i.e., senior police management):

When it's an FNO [foreign national offender] I have to do an ACRO check, I have to wait and see if an IS91 needs doing... so, if immigration are involved and it's a lot more of a formal process. I have to follow the flags raised on the system... it's different to say like a charge, caution or an NFA [no further action]... something straightforward like.

The electronic nature of the records also seemed to validate the accuracy of information in some officers' eyes. One police officer describing 'Niche', a database system to manage records, asserted:

It's not often that the system is wrong. Slow, but hardly wrong. It's actually difficult to override the information you have to put in and it's the shareability of it that's a gem... [it] makes the information richer and more reliable really. Forces are feeding into the same platform now, so we all see the same information.

Words such as 'seamless', 'data sharing' and 'linked' were used by officers to describe 'Niche', which was most valued for its ability to update in 'real-time', meaning that officers felt confident that the information was the most accurate. At times this function was perceived as superseding human capabilities: 'the system gathers evidence much more quickly than we mere humans can', one officer animatedly exclaimed. Another stated that 'the way it builds case files makes me know what I'm doing.' Consistency of service, allowing time to deal with victims and streamlining were emphasized as being possible because of the various computer technologies, which by virtue of their organizational intelligence, were perceived to allow a focus on operational policing. Computers and gadgets were regularly anthropomorphized to convey their value and to deflect decision-making or guilt on the officer's part. 'The computer tells me that' was a phrase I heard often. 'She's playing up today' was 
said by one officer to another when referring to his mobile device. 'Without this baby, I'd be literally lost', another remarked when there was a threat of the data on his computer being corrupted (Sundar, 2004; Epley et al., 2007).

At other times the electronic systems assuaged concerns about the racial disproportionality that was made visible; 'well, I don't make up the histories, do I?' one officer nonchalantly claimed after a black Sierra Leonean foreign national male had been brought in on suspicion of intent to supply drugs. He went on: 'so, I deal with what a nominal' is showing me about whether he's known to the police and what he's been charged for previously. I'm not even looking first off at ethnicity or where they live. The immigration check has to also happen now with the new policy.' Activities such as accessing and storing information, raising flags, checking citizenship status and retrieving data were regarded as though they were procedurally neutral and beyond the control of officer discretion. Even further, the influential power of human interpretation was masked. For example, an officer told me that live updates on a person's custody record meant that it was like he was watching over multiple custody suites at the same time and that he didn't even really need to physically be anywhere. Another sergeant told me: 'Databases like these have meant that policing can be done from afar, when necessary... I can look at the objective data and use that to make a decision, rather than what the person acts like or looks like'. The dehumanizing effects of technology are not necessarily particular to policework. However in support of previous research, the findings here show how through their use of technology and the associated expansion of data and types of information that could be instantly accessed, police officers' decision-making processes and accountability appeared to become more diffuse whilst nevertheless reproducing hierarchies of order on the basis of race, citizenship, gender and class (Ericson and Haggerty, 2008; Reiner, 1992).

\section{Police custody, racial optics and surveillance}

Whilst the introduction of technology often evokes the idea of recent and high end innovation, I also saw how traditional forms of technology had firmly become part of police culture in custody (Newburn and Hayman, 2002). Closed Circuit Television recording (CCTV), a now ubiquitous aspect of everyday life, was introduced in custody cells and other areas of police stations used for holding suspects in the late 1990s to safeguard officers as well as those held in custody, and to provide vital evidence should anything untoward occur. The cameras in all the custody suites I saw linked to a central screen at the front desk accessible by the custody sergeant and custody detention officers, enabling all or a number of the cells to be simultaneously observed. CCTV formed a component of the various types of information and intelligence that the police collated and added to the aim to construct a whole picture of someone or their identity, akin to the 'surveillant assemblage' described by Haggerty and Ericson (2000) which relies on the recording of discrete observations, transforming the body into pure information. One sergeant commented: 'it's brilliant that I can see all of them at the same time or focus in on one aspect about someone that might be concerning me. I can't physically be in several places at once, but this means I can', evoking the superhuman aspects that technology could conjure (Koper et al., 2015).

From my observations, it was very clear that camera technology in custody suites was appreciated by officers and had significantly changed the social and organizational conditions of officer-suspect interactions. The culture of policing also shaped the application of technology as others have noted (Chan, 2001; Newburn and Hayman, 2002; Manning, 2008). The use of cameras, which, for example, enabled the remote surveillance of detainees on screens, also effected the sense of distance and disconnection between suspects and the police. At times I saw how this allowed stereotypes and everyday racism to circulate. On one occasion an officer was watching a cell on screen closely after having physically gone into the same cell to offer a black Somalian foreign national suspect a mobile

\footnotetext{
${ }^{4}$ A record on a computer system which will provide an individual's known personal details. Examples of information which may be stored on a nominal record include criminal history, intelligence, associates, vehicles, addresses and warning markers.
} 
phone so he could call a solicitor. The suspect took the phone and threw it at the custody sergeant narrowly missing his head and had to be restrained by the custody detention officer. On returning back to his seat at the charge desk, the sergeant clicked the computer screen and focussed in on the cell he had just been in. The detention officer came a few minutes later and looked at the screen too and stated aloud, 'Look at you. Going round and round, like an animal. Something's not right there, is it mate.' The detention officer and sergeant were naturally aggrieved at the act of violent defiance by the detainee and the comments the officer made thereafter should be read in context of that incident and within an understanding of the very real pressures that officers face. Officer comments such as 'it's a thankless task' and 'you try and help and you get so much abuse' were often and fairly made. In this particular instance, the suspect was a black foreign national man, referred to as an animal and was watched by police officers and police staff from afar as they vented their frustrations in language laden with racial implications. These inferences may have been obscure or cushioned by ambiguity, but the surveillance licensed their expression.

Animalization and savagery have been integral to the history of racist representation, and such taxonomies are folded into the historical play of racial formations (Valluvan, 2016: 2245). As postracial denial of racism gathers pace, the articulation of degrading animalization becomes more prevalent; the preferred expression of postraciality. Goldberg (2015) explains that perversely, the illusory postracial condition we find ourselves in, increases the likelihood of people using animalistic terminology precisely because it appears to expunge racially explicit phrases from antagonistic terminology. I witnessed a Vietnamese foreign national woman brought in suspected for a drug offence and heard the arresting officer casually say 'she's more than likely a mule.' Another described a different suspect as 'a snake' referred to another as 'what a baboon'. Referring to detainees as animals would undoubtedly have been defended for not being racist by the officers, and because the detainees were unaware of the terms being directed to them or because they might have been applied to many (regardless of race or gender) or describing the offence rather than the suspect. However, using such words and practices around the custody suite and their direction towards visible ethnic minority suspects in particular and more often in reference to them, animated racism. I observed that expressions of animalizing language were most frequently directed towards suspected foreign national offenders and illegal migrants in custody, whose choices to travel were described as anathema to many officers. Though I did not meticulously compare the language used towards white and racial minority suspects, I did hear animalistic terms about the latter group more frequently. The dehumanization of black people by police officers and the use of force against black people has been positively correlated in US scholarship (Owusu-Bempah, 2017; Goff et al., 2014), however such work remains mainly in the realm of implicit bias analysis. In contrast, the instances I witnessed typified postracial racism; where a racial subtext is pressed without an accompanying racial text (Valluvan et al., 2013: 171). The day to day policing of migrants thus affirmed one of the most insidious aspects of postraciality; which is that far from ending racial discrimination, it is its sterilizing erasure of once explicit racist expression; its dis-appearance (Goldberg, 2015).

Closed circuit television also enabled a palpable sense of the disconnection between officers and detainees and the latter's almost disembodied and abstract presence. Despite the fact that the cells were only a corridor walk away, watching the individuals on screen hardened how the suspects were perceived and seemed to dissipate any identification with the frustration and fear that the detainees may have felt whilst being placed in the cells. As one officer said: 'it's weird, you have to remember they are just round the corner... I've found myself forgetting that sometimes'. Another claimed, 'you know, seeing them on screen kinda ... well, it makes it surreal almost. Do you know what I mean? It's like they are so near... yet so far.' I noticed that on the screens, the detail of the faces and expressions of the suspects were blurred and highly pixelated and often all that could be discerned was the shape of the bodies and their colour. I wondered what effect the erasure of the expressions and facial features of the detainees had on officers who watched images like this day after day. I thought about the oscillating sentiments of the officers who would be in person reading someone their rights face to face and then minutes later spectating, scrutinizing and tracking the detainees' movements on a screen.

The capacity of images on screen to numb responses particularly when observing 'others' and those from who 'we' feel distant, has been powerfully argued (Sontag, 2003); in a number of instances in the custody suites, I witnessed the ways that observing detainees on a screen prompted racialized emotions to be expressed, in sometimes unexpected ways. The same officers that expressed nuanced 
understandings of police practice and its relationship with racially disproportionate outcomes and the importance of strategies for diversity, also at times made racially inappropriate comments when they felt personally challenged by suspects who were aggressive towards them or didn't quite fit the expectations officers had of criminals. I found support for the idea that emotional economies are attached to race and tend to foreclose cognitive receptivity, and that feelings often trump facts in respect to race (Ioanide, 2015), the presence of racism without racists (Bonilla-Silva, 2018). This 'new racism' (without racists) is described in such a way because despite the common-sense view that people no longer see or would label themselves as racist nevertheless racism persists, is real and tenacious (Memmi, 2000). Although colour blindness, fairness and equality are espoused in policies to promote respect for diversity in the sphere of policing, in reality racism exists in subtle, sophisticated and structural forms, ensuring it delimits and scars the lives of visible ethnic minorities. This then typifies the postracial paradox; instead of the notion that race no longer matters being fulfilled, the reality is that race-making processes and racism have become increasingly covert, diffuse and deniable. I saw officers directing their anger and frustration at the computer screens, and the fact that the suspects did not know they were being watched and could not speak back or hear the comments that were made, meant that verbal abuse, disgust, racism and pity could be directed at the person in the cell without them hearing or seeing it. Such acts, though seemingly innocuous, allowed racism to circulate and become part of the everyday - felt ${ }^{5}$, but hard to locate (Gordon, 1995).

Even as racism permeated the police station's spaces and walls, it was something you still just could not quite put your finger on (Tate, 2016). For example, one detention officer, when watching a black foreign national male eating a meal, tracked him on the screen with palpable contempt perhaps because the suspect had complained about the food he was given earlier. The officer mockingly talked to the screen, 'no chicken and chips for you today mate'. In another, an officer watched silently as a Pakistani foreign national man knelt down and prayed, remarking how it was incongruous that the praying suspect had just held a woman at knifepoint in Sainsbury's supermarket. Thus I saw how ambivalence rather than racial explicitness defined contemporary racism in the context of criminal justice safety management. Although the combination of watching, monitoring and checking various databases offered safety and well-being for both detainees and officers, it also created opportunities for unguarded expressions of racial animosity and selective treatment towards racial others by the police officers and staff. The capacity for suspects' lives to be remotely observed on CCTV offered a conduit through which racism could circulate through surveillance and manifest silently and informally (Goldberg, 2015; Browne, 2015). Instances of anger and frustration towards those held in custody were often expressed towards all suspects regardless of their race. However, in my observations I saw that visible minority ethnic group individuals and particularly foreign nationals suspects of a crime were more likely to be discussed in such terms because they were seen as culturally distant from the officers. There was less perceptible empathy expressed for the potential reasons and circumstances that might have resulted in these individuals having been brought into police custody. More sympathy was shown towards migrants who had been picked up by the police via a lorry drop, but even then, this was usually expressed with an aura of condescension by police and custody detention officers about why they would choose to endure travelling in such dangerous conditions.

\section{Conclusion: Ineluctable Racial Technologies?}

This article advances a claim for further critical examination towards the intersections between social studies of technology, race, criminal justice and border control. In the discussion above, I have shown how the use of technology in policing can have racializing consequences despite claims that technology may be neutral or applied evenly to all. Given that everyday racism is present in many practices (Essed, 1991; Smith, 2016; Goldberg, 1993), including police work, criminalized and racialized identities are arguably perpetuated through policing as it innovates technologically and through collaborative initiatives such as Operation Nexus. Through observing how technologies and their use in policing to identify and monitor foreign nationals suspected of offending operates, we see that the focus on racialized groups is understood as a logical response to control migration and, consequently, racist

\footnotetext{
${ }^{5}$ For further discussion on my own positionality and how I witnessed and felt these instances of racism, see Parmar A. (2018b) Race at the Border In: Fili A, Jahnsen S and Powell R (eds) Criminal Justice Research in an Era of Mass Mobility. Abingdon: Routledge, 186-200.
} 
intent and/or outcomes are disavowed. Because nationality and histories of offending are used as a rationale for deciphering 'good' from 'bad' migrants, migration control's racialized logics remain concealed and displaced through the procedures of police identification and categorization (Dhaliwal and Forkert, 2015). Such practices are of course not confined to police custody and rather are part of the broader policing continuum. Research has long shown that racial surveillance and exclusionary practices are reproduced through street policing and how ordinary policing is routinely implicated in checking nationality and enforcing migration control (Parmar, 2011; Weber, 2011). Augmenting these established practices, in modern policing electronic databases are regularly accessed to 'verify' a suspect's identity and offending history. Often, assumptions are made that the data on which technology draws is objective and unfettered by previous instances of racial profiling, human discretion or error (Bridle, 2018). In contrast, as discussed in this paper, I was able to document how technology contributed to the production of societal racial hierarchies through the practices of migration policing and joint working with immigration officers and ACRO, and how this distanced police officers from decisions and non-decisions that were taken on a daily basis. All of these 'bottom up' processes underscore how the daily practices of institutional actors enable state power to emerge and embed to form the police-immigration complex (Gravelle et al., 2013; Armenta, 2016).

It is hoped that the research presented in this paper signals the merit of looking at micro-level interactions to understand collaborative working between agencies and the police rather than assuming that such partnerships are a panacea for achieving tighter and deeper migration control. Future research could also be attentive to the possibilities of resistance against racialization through technology (Gilroy, 1993). Overall it is clear that the ostensible aim of technologies to quell uneven practices such as racial profiling, can end up misaligning with those stated aims or being directly inimical to them; instead further racializing vulnerable groups under the cloak of impartiality. The findings therefore invite us to reflect upon whether surveillance and digital technologies applied in criminal justice spaces are a Pandora's box, releasing more racializing terrors rather than delivering promised colour-blind or postracial riches. Given that the expansion of technologies in policing and the impetus for the police to respond to migration control seem ineluctable, revealing how these processes function to (re)produce race through criminal justice policies, partnerships and practices is both vital and urgent. 


\section{REFERENCES}

Aas KF. (2006) 'The body does not lie': Identity, risk and trust in technoculture. Crime, Media, Culture: An International Journal 2: 143-158.

Ahmed S. (2000) Strange Encounters: Embodied others in Postcoloniality, London: Routledge.

Aliverti A. (2015) Enlisting the Public in the Policing of Immigration. British Journal of Criminology 55: 215-230.

Amar P. (2010) Introduction: New racial missions of policing: comparative studies of state authority, urban governance, and security technology in the twenty-first century. Ethnic and Racial Studies 33: 575-592.

Armenta A. (2016) Racializing Crimmigration. Sociology of Race and Ethnicity 3: 82-95.

Benjamin R. (2016) Catching Our Breath: Critical Race STS and the Carceral Imagination. Engaging Science, Technology, and Society 2: 145-156.

Bennett Moses L and Chan J. (2018) Algorithmic prediction in policing assumptions evaluation and accountability. Policing and Society 28.

Bolt D. (2016) An Inspection into the Extent to which the Police are Identifying and Flagging Arrested Foreign Nationals to the Home Office and Checking theiir Status Independent Chief Inspector of Borders and Immigration

Bonilla-Silva E. (2018) Racism Without Racists: color-blind racism and the persistence of racial inequality in America, Lanham: Rowman \& Littlefield.

Bosworth M and Guild M. (2008) Governing through Migration Control. British Journal of Criminology 48: 703-719.

Bowles N. (2016) 'I think my blackness is interfering': does facial recognition show racial bias? The Guardian.

Bridle J. (2018) New Dark Age: Technology and the End of the Future, London: Verso.

Brouwer J, Van Der Woude M and Van Der Leun J. (2017) Border policing, procedural justice and belonging: the legitimacy of (cr)immigration controls in border areas. The British Journal of Criminology.

Browne S. (2015) Dark Matters: On the Surveillance of Blackness, Durham: Duke University Press.

Buolamwini J. (2018) Gender Shades: Intersectional Accuracy Disparities in Commercial Gender Classification. Fairness, Accountability and Transparency. 1-15.

Byfield NP. (2018) Race science and surveillance: police as the new race scientists. Social Identities: $1-16$.

Chan J. (2001) The Technological Game. How information technology is transforming police practice Criminology and Criminal Justice 1: 139-159.

Cole S. (2002) Suspect Identities. A History of Fingerprinting and Criminal Identification, Cambridge Massachussets: Harvard University Press.

Coudert F, Butin D and Le Métayer D. (2015) Body-worn cameras for police accountability: Opportunities and risks. Computer Law \& Security Review 31: 749-762.

Dhaliwal S and Forkert K. (2015) Deserving and Undeserving Migrants Soundings 61: 49-61.

Epley N, Waytz A and Cacioppo J. (2007) On Seeing Human: A Three-Factor Theory of Anthropomorphism. Psychological Review 114: 864-886.

Ericson R and Haggerty K. (2008) Policing the Risk Society, Oxford Oxford University Press.

Essed P. (1991) Understanding Everyday Racism: An Interdisciplinary Theory London: Sage.

Ferguson AG. (2017) The Rise of Big Data Policing. Surveillance, Race, and The Future of Law Enforcement, New York: New York University Press.

Fiske J. (1998) Surveilling the City: Whiteness, the Black man and Democratic Totalitarianism. Theory, Culture \& Society 15: 67-88.

Foster J. (2003) Police Cultures. In: Tim N (ed) Handbook of Policing. Cullumpton: Willan.

Foster J, Newburn T and Souhami A. (2005) Assessing the Impact of the Stephen Lawrence Inquiry. Home Office Research Studies London: Home Office

Garvie C, Bedoya A and Frankle J. (2016) The Perpetual Line-Up: Unregulated Police Face

Recognition in America. Georgetown Law, Center on Privacy and Technology.

Gilroy P. (1993) The Black Atlantic: Modernity and the Double Consciousness, London: Verso. 
Goff PA, Jackson MC, Di Leone BA, et al. (2014) The essence of innocence: consequences of dehumanizing Black children. J Pers Soc Psychol 106: 526-545.

Goldberg DT. (1993) Racist Culture, Oxford: Blackwell.

Goldberg DT. (2015) Are we all postracial yet?, Cambridge: Polity.

Gordon LR. (1995) Fanon and the Crisis of European Man: An Essay on Philosophy and the Human Sciences, London: Routledge.

Gordon P. (1985) Policing Immigration: Britain's Internal Controls London: Pluto Press.

Gravelle M, Ellermann A and Dauvergne C. (2013) Studying Migration Governance from the Bottom-Up. In: Anderson B, Gibney M and Paoletti E (eds) The Social, Political and Historical Contours of Deportation. New York: Springer.

Griffiths M. (2017) Foreign, criminal: a doubly damned modern British folk-devil. Citizenship Studies 21: 527-546.

Grossmith L, Owens C, Finn, et al. (2015) Police, Camera, Evidence: London's cluster randomised controlled trial of Body Worn Video. College of Policing and MOPAC.

Haggerty K and Ericson R. (2000) The Surveillant Assemblage. British Journal of Sociology 51.

Hannah-Moffat K and Maurutto P. (2010) Re-contextualizing pre-sentence reports: Risk and race. Punishment \& Society 12: 262-286.

HMIC. (2015) The Welfare of Vulnerable People in Police Custody. London: Her Majesty's Inspector of Constabulary

Home Office. (2017a) Operation Nexus- High Harm. London: Home Office

Home Office. (2017b) Race Disparity Audit. Summary Findings from the Ethnicity Facts and Figures website London Cabinet Office

Ioanide P. (2015) The Emotional Politics of Racism, Stanford: Stanford University Press.

Joh E. (2007) Discretionless Policing: Technology and the Fourth Amendment. California Law Review 95: 199-234.

Koper CS, Lum C and Hibdon J. (2015) The uses and impacts of mobile computing technology in hot spots policing. Evaluation Review 39: 587-624.

Loftus B. (2008) Dominant Culture Interrupted: recognition, resentment and the politics of change in an English Police Force. British Journal of Criminology 48: 756-777.

Loftus B. (2009) Police Culture in a Changing World, Oxford Oxford Univeristy Press.

Loftus B. (2013) Border regimes and the sociology of policing. Policing and Society 25: 115-125.

Lum C, Koper CS and Willis J. (2016) Understanding the Limits of Technology's Impact on Police Effectiveness. Police Quarterly 20: 135-163.

M'charek A, Schramm K and Skinner D. (2014) Topologies of Race. Science, Technology, \& Human Values 39: 468-487.

Maguire M. (1988) Effects of the "P.A.C.E" provisions on detention and questioning: some preliminary findings. British Journal of Criminology 28: 19-43.

Manning P. (2008) The Technology of Policing: Crime Mapping, Information Technology, and the Rationality of Crime Control, New York: New York University Press.

Memmi A. (2000) Racism, Minneapolis: University of Minnesota Press.

Mezzadra S and Neilson B. (2013) Border As Method, Or the Multiplication of Labor, Durham: Duke University Press.

Muller BJ. (2004) (Dis)qualified bodies: securitization, citizenship and 'identity management'. Citizenship Studies 8: 279-294.

Mutsaers P. (2014) An Ethnographic Study of the Policing of Internal Borders in the Netherlands. British Journal of Criminology 54: 831-848.

Newburn T and Hayman S. (2002) Police, Surveillance and Social Control: CCTV and Police Monitoring of Suspects Cullumpton: Willan Publishing

Noble SU. (2018) Algorithms of Oppression. How Search Engines Reinforce Racism, New York: New York University Press.

Oswald M, Grace J, Urwin S, et al. (2018) Algorithmic risk assessment policing models lessons from the Durham HART model and Experimental proportionality. Information and Communciations Technology Law 27.

Owusu-Bempah A. (2017) Race and policing in historical context: Dehumanization and the policing of Black people in the 21st century. Theoretical Criminology 21: 23-34. 
Parmar A. (2011) Stop and search in London: counter-terrorist or counter-productive? Policing and Society 21: 369-382.

Parmar A. (2016) Race, Ethnicity and Criminal Justice: Refocussing the Criminological Gaze. In: Bowsworth M, Hoyle C and Zedner L (eds) Changing Contours of Crimina Justice Oxford: Oxford University Press, 55-68.

Parmar A. (2018a) Policing Belonging: Race and Nation in the UK. In: Bosworth M, Parmar, A. and Vazquez, Y. (ed) Race, Criminal Justice, and Migration Control: Enforcing the Boundaries of Belonging Oxford: Oxford University Press, 108-124.

Parmar A. (2018b) Race at the Border In: Fili A, Jahnsen S and Powell R (eds) Criminal Justice Research in an Era of Mass Mobility. Abingdon: Routledge, 186-200.

Ray R, Marsh K and Powelson C. (2017) Can Cameras Stop the Killings? Racial Differences in Perceptions of the Effectiveness of Body-Worn Cameras in Police Encounters. Sociological Forum.

Reiner R. (1992) Policing a Postmodern Society. The Modern Law Review 55: 761-781.

Reiner R. (2010) The Politics of the Police Oxford Oxford University Press.

Skinner D. (2018) Race, Racism and Identification in the Era of Technosecurity. Science as Culture: $1-23$.

Skinner D and Rosen P. (2001) Opening The White Box: The Politics of Racialised Science and Technology. Science as Culture 10: 285-300.

Skinns L. (2011) Police Custody. Governance, legitimacy and reform in the criminal justice process, Abingdon: Willan.

Smith A. (2016) Racism and Everyday Life, Basingstoke: Palgrave. .

Sontag S. (2003) Regarding the Pain of Others St Ives Penguin.

Stumpf J. (2006) The Crimmigration Crisis: Immigrants, Crime, and Sovereign Power. American University Law Review 56: 367-419.

Sundar SS. (2004) Loyalty to computer terminals: is it anthropomorphism or consistency? Behaviour \& Information Technology 23: 107-118.

Tate SA. (2016) I can't quite put my finger on it: racism's touch. Ethnicities 16: 68-85.

Valluvan S. (2016) What is 'post-race' and what does it reveal about contemporary racisms? Ethnic and Racial Studies: 1-11.

Valluvan S, Kapoor N and Kalra V. (2013) Critical Consumers Run Riot in Manchester Journal for Cultural Research 17: 164-182.

Vine J. (2014) An inspection of Immigration Enforcement activity in London and the West Midlands ('Operation Nexus'). Independent Chief Inspectior of Borders and Immigration.

Voigt R, Camp NP, Prabhakaran V, et al. (2017) Language from police body camera footage shows racial disparities in officer respect. Proc Natl Acad Sci U S A 114: 6521-6526.

Waddington PAJ. (1999) Policing Citizens: Authority and Rights London: Routledge

Wajcman J. (2017) Automation: is it really different this time? Br J Sociol 68: 119-127.

Weaver M. (2017) Rashan Charles death: Met officer investigated for gross misconduct. Guardian.

Weber L. (2011) "It Sounds Like They Shouldn't Be Here": Immigration checks on the streets of Sydney. Policing and Society 21: 456-467.

Weber L. (2013) Policing Non-Citizens, Abingdon: Routledge.

Weber L and Bowling B. (2004) Policing Migration: A Framework for Investigating the Regulation of Global Mobility. Policing and Society 14: 195-212.

Woof A and Skinns L. (2017) The role of emotion,space and place in police custody in England: Towards a geography of police custody. Punishment and Society 0(0): 1-18.

Yeo C. (2017) Free Movement, 'Home Office belatedly issues guidance on Operation Nexus', 24 April 2017.

Yuval-Davis N, Wemyss G and Cassidy K. (2018) Everyday Bordering, Belonging and the Reorientation of British Immigration Legislation. Sociology 52: 228 - 244. 


\section{Funding}

The author acknowledges with great appreciation the support of the John Fell Oxford University Press (OUP) research fund, from which this publication arises.

\section{Acknowledgements}

The author thanks her participants and Rod Earle, Coretta Phillips, Amanda Porter, Sarah Turnbull, Kate West and the $B J C$ 's anonymous reviewers for their valuable insights and constructive comments on earlier drafts of this paper. 